\title{
Ecclesiastical strategy as a factor on territorial organization in Santa Ana de Guadalupe, Jalisco, Mexico
}

\author{
Carrillo-Llanos, Sonia ${ }^{1^{*}}$; Escalona-Maurice, M. J. ${ }^{2}$; Jiménez-Moreno, M. J. ${ }^{2}$
}

${ }^{1}$ Universidad de Guadalajara, La Martinica, Zapopan, Jalisco, México. ${ }^{2}$ Colegio de Posgraduados,

Campus Montecillo, Texcoco, Estado de México, México.

*Corresponding author: soni.carrillo@gmail.com

\begin{abstract}
Objective: The objective was to study the territorial organization strategy of local actors; church, government and population that influenced the evolution and current organization of the town of Santa Ana de Guadalupe after the canonization of the priest Toribio Romo.
\end{abstract}

Design/Methodology/Approach: The local development methodology was applied, through specific interviews with representatives of social partners; local church, government, and population.

Results: It was found that the infrastructure and equipment of the Saint's Temple, which receives more than 700 thousand visitors a year, shows potentialities, strengths and limitations at the locality. Analyzing the territory, through its economic, political, socio-cultural, and environmental axes, it was noted that local development is a process of growth and structural change in which the main interest of the town is to increase employment and meeting the needs and demands of religious pilgrims. As well as favor the appropriate use of the resources, and over-all potential of the locality in order to improve the standard of living of the population.

Limitations of the study/Implications: The strategies of cooperation and knowledge of the ecclesiastical agents in conjunction with the government and local population through joint organization contribute to the transformation of Santa Ana de Guadalupe.

Findings/Conclusions: It was observed that social partners (church, government and population) collaborate actively. Particularly in ecclesiastical activities to develop strategies (as organization and cooperation) to promote the local development.

Keywords: local development, social partners, religious activities.

\section{INTRODUCTION}

Complex proceseses are oriphated in areas such as economic, social and environmental for solving problems. With the socio-economic actors in charge of developing alternatives to face these situations (Boisier, 2004; Rodríguez, 2009).

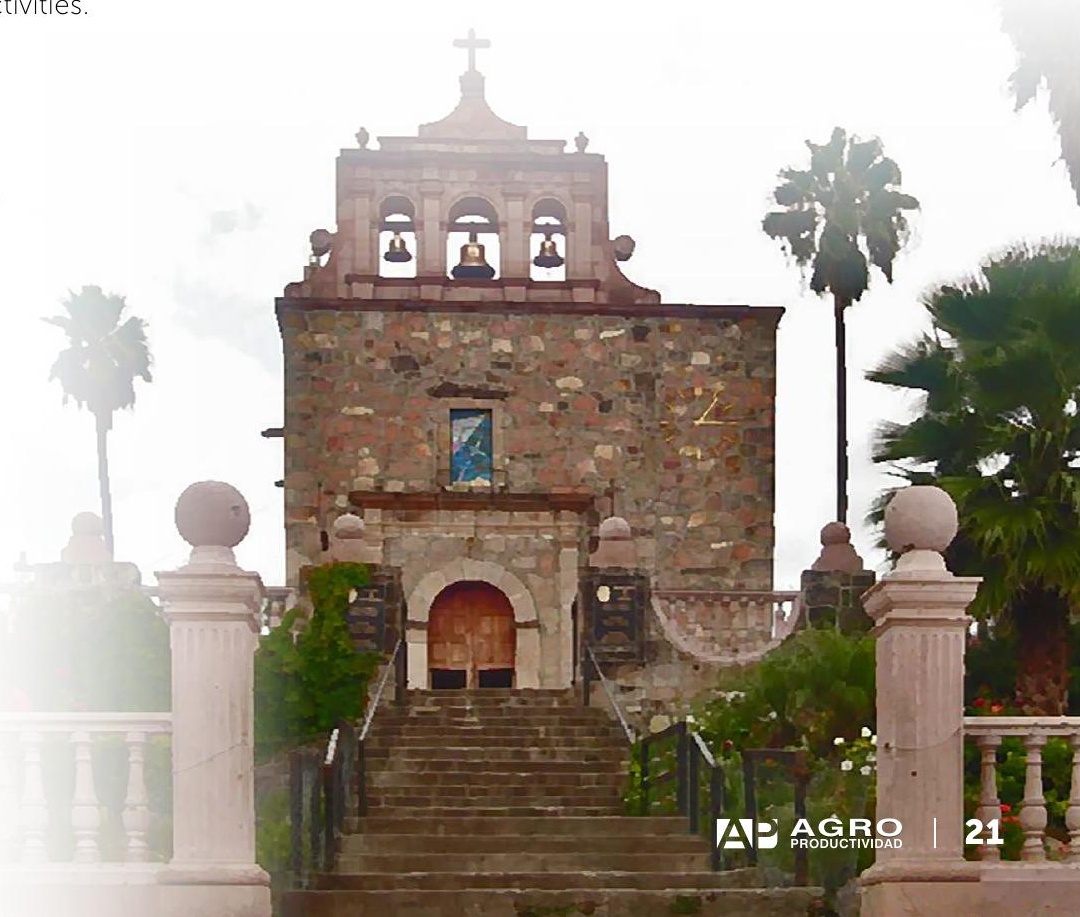


Local development is a process of growth and structural change through the proper use of resources and potentialities of the territory (Arocena, 1995; Cardenas, 2002; In order to be feasible, local development should adopt more comprehensive visions i.e. analyzing the territory in the economic, political, socio-cultural and environmental axes (Armas, Tamayo and Santos, 2017). For example, in analysis of the spatial concentration of economic activities, they are not located in a uniform way on the territory, but tend to be located in certain areas, with the objective of taking advantage of the benefits that arise from being located close to other areas, or to those of demand generated by consumers (Arocena, 1995; Cárdenas 2002).

The aim is to understand, tending towards local development processes, linked to the trust that already exists among social partners in the community, to those behavioral norms and levels of association ability. The strengthening of relations among social partners is an aspect of great importance for the territory (García, 2008; Aurajo, 2016).

The actors establish the organization of the modes of appropriation, cooperation and knowledge of common problems. Such strategies are decisive for local development (Cárdenas, 2002; Balente-Herrera, Díaz-
Puente and Parra, 2012). Religious activities appear as critical in the development of human beings, as well as agent in the transformation of common territory.

The impact of canonization of the Saint Toribio Romo in the town of Santa Ana de Guadalupe allowed the development of different activities, as well as various types of concentrations related to religious phenomena (Aguilar, 2016). The objective of this research was to study the territorial organization strategy of local social partners; church, government and population, that affected the current local evolution at Santa Ana de Guadalupe town, after canonization of the priest Saint Toribio Romo.

\section{MATERIALS AND METHODS}

Study area. Santa Ana de Guadalupe is located at kilometer 0.9 of the Jalostitlán-San Miguel el Alto State Highway (Figure 1). The town belongs to the municipality of Jalostitlán in a region called Los Altos de Jalisco. Santa Ana de Guadalupe is administratively considered just as a settlement, because it has a small rural population, with 151 men and 160 women (INEGI, 2010)

The local development methodology was used (Arocena, 1995; Boisier, 1999, 2004; Cepal 2012). Specific interviews were applied to representatives of

LOCALIZACION DE SANTA ANA DE GUADALUPE

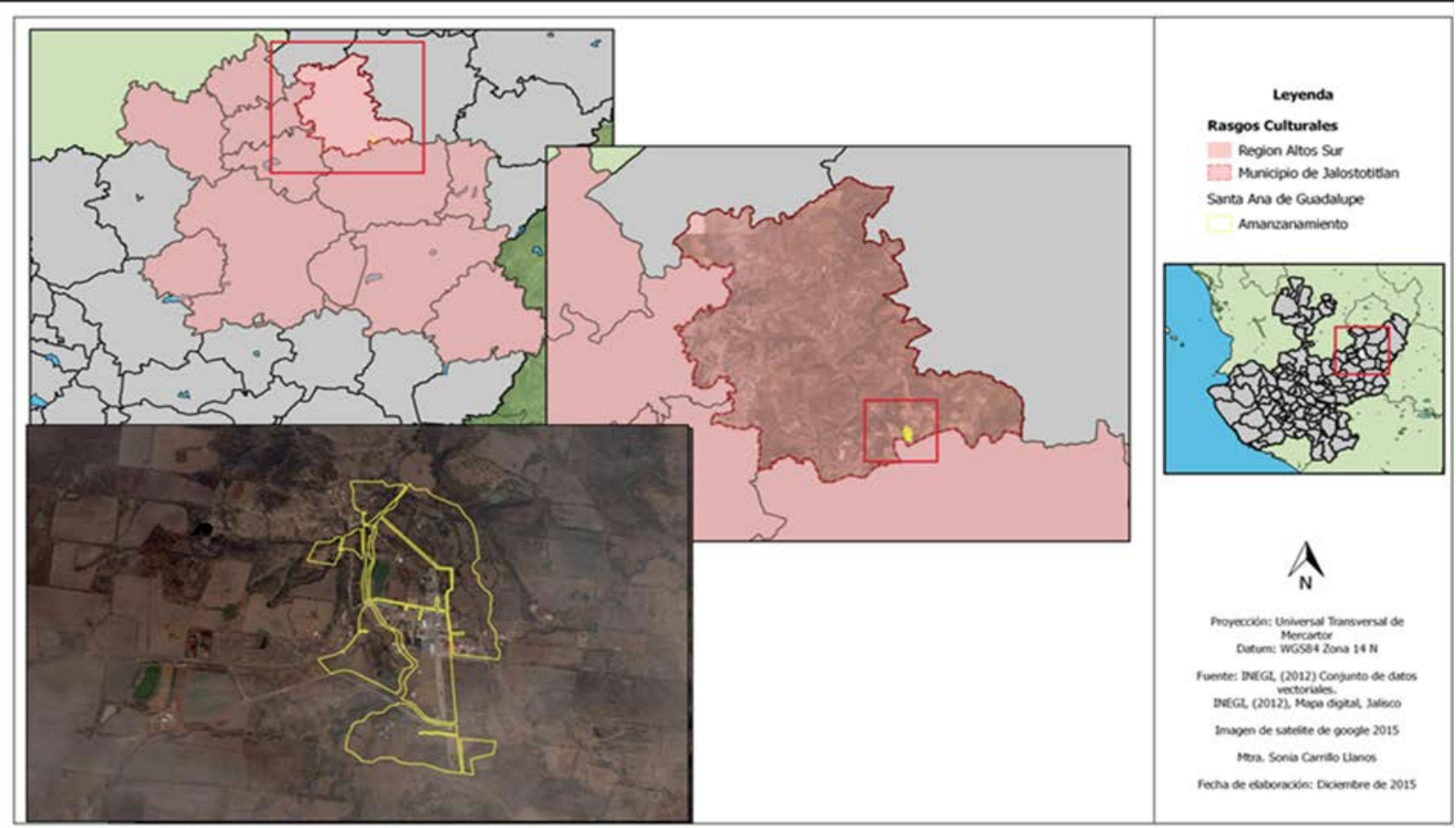

Figure 1. Location map of Santa Ana de Guadalupe territory (Jalostitlan, Jalisco, Mexico) Source: Own elaboration with information from INEGI (2012). 
social partners: church, government, and population, designing a partner-specific type of interview for each partner type. Also, we used a questionnaire known as Ethno survey (University of Princeton and University of Guadalajara, 2012), as well as fieldtrips.

\section{RESULTS AND DISCUSSION}

Based on the field trips and interviews, it was observed that at the locality of Santa Ana de Guadalupe, in Los Altos de Jalisco, a popular holiday of the saint Toribio Romo is being developed (Fábregas, 1986; Meyer, 1994). This saint was born at the town; and the holiday started as a family-matter and a regional network, making news to extend it. His canonization was an important factor as an ecclesiastical strategy, because shortly after the canonization, a temple was built for their devotion, which is one of the most visited at the national scale (Table 1).

Visitors counting both, pilgrims, and merchants, is greater than 750 thousand a year (Martínez, 2009), thus generating great economic resources income for the town. De la Torre (1992) mentions that it is difficult to understand the success of the holiday of Santo Toribio; as he is one of the youngest Catholic Saints, canonized as a martyr priest in 2000 (Archbishopric of Guadalajara, 2014).

Such an ecclesiastical strategy was of paramount importance to the development of Santa Ana de Guadalupe, despite being a small rural town, in a short-term it generated local and regional sources of employment, because businesses occur not only at the locality, but in the nearby municipalities. And there arrive also merchants from other states of the country.
Regarding the regional production process that presented different transformations throughout its history, it evolved from a subsistence economy with family labor to an open process of regional market relations intermediaries, these activities impact on territory transformations.

On the other hand, infrastructure (Figure 2) of the town, in order to house the influx of people coming to visit the Saint Toribio is basic (water, electricity, drainage, etc.) Therefore, if this influx of pilgrims continues, it will require bigger services (hotels, public parks, etc.) and instruments must be created that allow sustainable use of resources for local development.

Regarding the socio-territorial problem, it was found that the effect on the territory generated various facilities and infrastructure, but there is no solid territorial organization based on planning. Due to people influx to the area, it is essential to timely rectify incipient situations of contamination, pilgrims, agglomeration, demand for services, so that the location would progress efficiently and sustainably.

\section{CONCLUSIONS}

It was observed that social partners (church, government, and population) actively collaborate, specifically in ecclesiastical activities for the development of strategies (as organization, and cooperation) in order to satisfy the needs and demands of pilgrims, and to promote local development at Santa Ana de Guadalupe.

\section{REFERENCES}

Aguilar R. A. (2016). El santuario de Santo Toribio romo en lo altos jaliscienses: La periferia en el Centro. Nueva antropol 29(84): 91-116.

\begin{tabular}{|c|c|c|c|c|}
\hline Temple & Condition & Location & Space & Annual influx \\
\hline Guadalupe's Virgin & Mexico City & Federal District & Urban & 15 million \\
\hline Virgin of Zapopan & Jalisco & Zapopan, & Urban & 3 million \\
\hline Virgin of the Rosary of Talpa & Jalisco & Talpa de Allende & Rural & 3 million \\
\hline The Holy Child of Atocha & Zacatecas & Silversmiths Fresnillo Zacatecas & Urban & 1.5 million \\
\hline Saint Toribio Romo & Jalisco & Santa Ana de Guadalupe Jalostotitlán & Rural & 750 thousand \\
\hline Virgin of Juquila & Oaxaca & Juquila & Rural & 500 thousand \\
\hline The Lord of Mercy & Jalisco & Tepatitlán de Morelos & Urban & More than 200 thousand \\
\hline
\end{tabular}

Source: Own elaboration with information from Martínez (2009). 


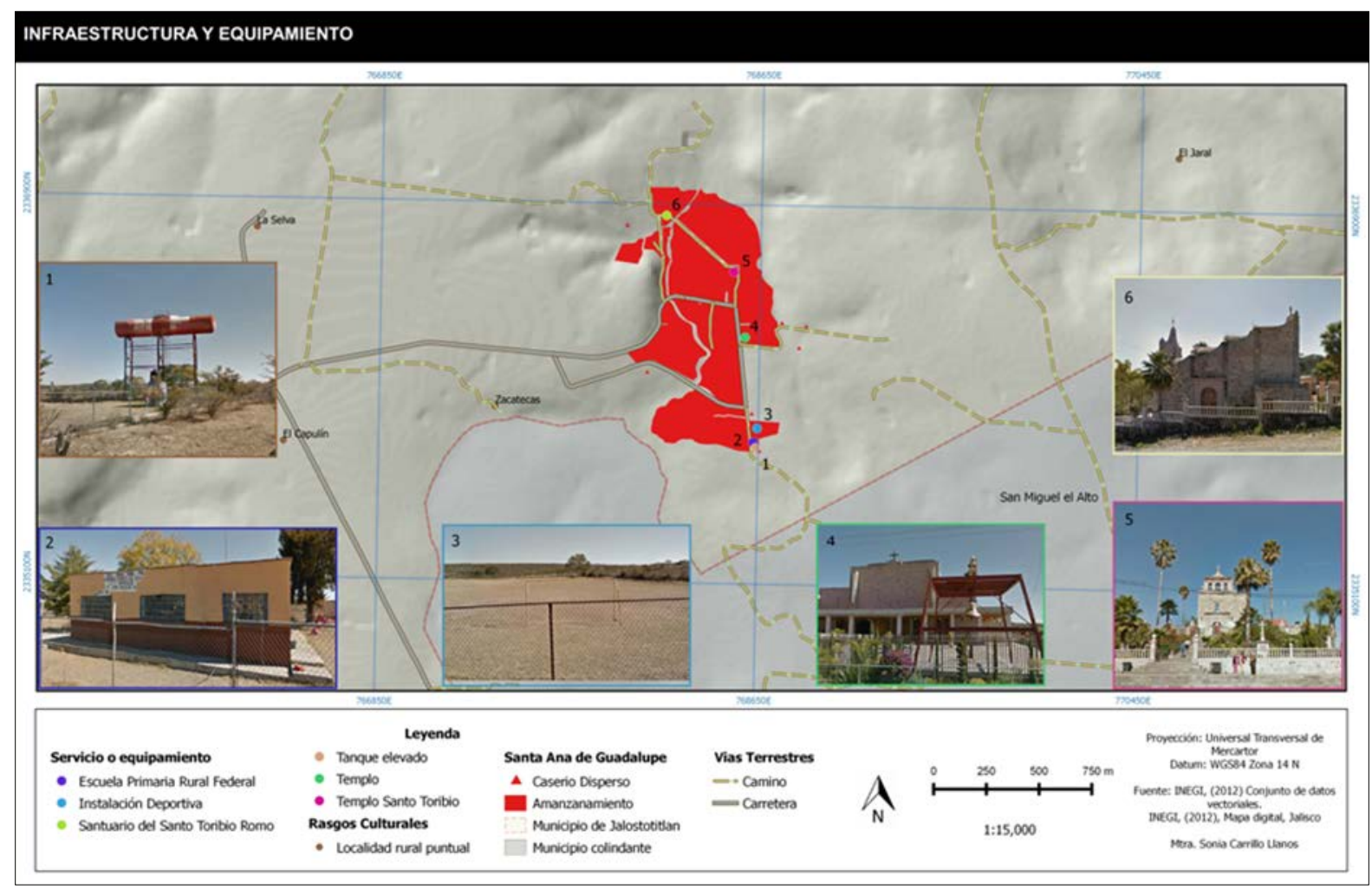

Figure 2. Map of infrastructure and equipment of Santa Ana de Guadalupe (Jalostitlan, Jalisco, Mexico). Source: Own elaboration with data from INEGI $(2010,2012)$.

Araujo G. R. (2016). Desarrollo local y trabajo comunitario: la experiencia del CEDEM-UH en el marco de PADIT. Rev. Nov. Pob, 12(24) 84-93.

Armas U. R., Tamayo, P. N. y Santos, R. M. (2017). Población, territorio y gestión para el desarrollo local sustentable. Rev. Nov. Pob. 13(26): 166-175

Arocena, J. (1995). El Desarrollo Local: un desafío contemporáneo Centro Latinoamericano de Economía Humana. Universidad Católica de Uruguay. Edit. Nueva Sociedad. Caracas.

Arzobispado de Guadalajara. (2014). Archivo sobre canonización https://arquidiocesisgdl.org/boletin/2012-9-8.php

Balente-Herrera, O., Díaz-Puente, J. M. y Parra V. M. R. (2012). Los determinantes del desarrollo local. Un estudio de caso en Chiapas, México. Agric. Soc. Desarrollo, 9:251-269.

Boisier, S. (1999). El desarrollo territorial a partir de la construcción de capital sinergético. Estudios Sociales, N99

Boisier, S. (2004). Desarrollo territorial y descentralización, el desarrollo en el lugar y en las manos de la gente. Revista EURE, vol. XXX. N.90. 27-40

Cárdenas, N. (2002). El desarrollo local su conceptualización y procesos. Provincia, 8: 53-76

Comisión Económica para América Latina y el Caribe (CEPAL) (2012) Metodología para la elaboración de estrategias de desarrollo local. ILPES. 99. https://www.cepal.org/es/publicaciones/5518metodologia-la-elaboracion-estrategias-desarrollo-local

De la Torre, R. (1992). Toribio a los altares, Periódico en Siglo 21. Guadalajara, 6 de marzo.
Fábregas, A. (1986). La formación histórica de una región: Los Altos de Jalisco. México. CIESAS. Colección Othón de Mendizabal 5:145-149

Fukuyama, F. (2000): "Social Capital and Civil Society". IMF Working Paper WP/00/74

García D. L. A. (2008). Jean Meyer, La cruzada por México. Los católicos de Estados Unidos y la cuestión religiosa en México. Estud. Hist. Mod. Contemp, 36: 279-285.

Instituto Nacional de Estadística y Geografía (INEGI). 2010. Censos y Conteos Nacionales. https://www.inegi.org.mx/programas/ ccpv/2010/

Instituto Nacional de Estadistica y Geografía (INEGI). 2012. Conjunto de datos vectoriales, mapa digital Jalisco. http://mapajalisco.gob. $\mathrm{mx} /$ mapajalisco/index.php

Martínez, C. R. (2009). Un Acercamiento al Turismo Religioso en Los Altos de Jalisco. Orbis. Revista Científica Ciencias Humanas, 5(13), 47-66

Meyer, J. (1994). La Cristiada. Tomos I, II y III. Siglo XXI editores, México. Rodríguez C. J. C. (2009). Los procesos de desarrollo local desde la perspectiva europea: génesis y transformación. Semestre Económico, 24(12): 37-55

Universidad de Princeton y Universidad de Guadalajara. (2012) El proyecto sobre Migración Latinoamericana (LAMP) y el Proyecto sobre Migración Mexicana son proyectos de investigación multidisciplinaria organizado por investigadores de Latino América y Estados Unidos. https://lamp.opr. princeton.edu/home-es.htm 